\title{
Simultaneous Effect of Ownership and Economic Sector on the Performance of Enterprises in Vietnam
}

\author{
Pham Quang Tin ${ }^{1}$, Pham Kim Ngoc ${ }^{1}$, Nguyen Tran Thuan ${ }^{1} \&$ Doan Gia Dung ${ }^{1}$ \\ ${ }^{1}$ University of Economics, The University of Danang, Danang, Vietnam \\ Correspondence: Pham Quang Tin, Department of Statistics and Informatics, University of Economics, The \\ University of Danang, 71 Ngu Hanh Son street, Danang city, Vietnam. Tel: 0084-914-112-618. E-mail: \\ quangtindn@gmail.com
}

Received: July 6, 2017

Accepted: October 25, $2017 \quad$ Online Published: October 30, 2017

doi:10.5539/ijef.v9n11p223

URL: https://doi.org/10.5539/ijef.v9n11p223

\begin{abstract}
This paper examines the differences in the impact of ownership types and economic sectors on the business efficiency of 4,733 enterprises in Vietnam by the year of 2015. By the method of analysis of variance (ANOVA), it is shown that while types of ownership, foreign, state and private ownership, have a significant and different impact on the performance of businesses, the difference in economic sectors does not affect the enterprise efficiency. In addition, when testing simultaneous effect of these factors, some findings are as follows: private-owned enterprises' efficiency in the manufacturing and service sectors is better than those in agriculture, forestry and fishing sector; conversely, foreign invested enterprises operating in agriculture, forestry and fishing sector own better performance than theirs in manufacturing and service sectors; state-owned enterprises in manufacturing and service sectors is very less efficient than theirs in agriculture, forestry and fishing sector.
\end{abstract}

Keywords: analysis of variance, economic sector, enterprise performance, ownership

\section{Introduction}

Vietnam has changed dramatically since the launch of early "doi moi" economic reform (Note 1) 1986. This strategic change has led to expand non-state and foreigned invested sectors (Note 2). In fact, in the long time before, the Vietnamese economy was dominated by state-owned enterprises and these enterprises enjoyed enormous benefits but they were quite inefficient. To resolve this problem, the privatization of state-owned enterprises have been boosted by the Vietnamese government since 1992. As a result, today in terms of types ownership, there exist three main forms of ownership in enterprises in Vietnam as below:

1) State-owned enterprises (SOEs): one-member limited liability companies with $100 \%$ of state-owned capital; joint-stock companies and limited liability companies with above $50 \%$ of state-owned capital.

2) Private-owned enterprises (POEs): types of cooperatives and unions of cooperatives; limited liability companies with less than $50 \%$ of state-owned capital; joint stock companies with less than $50 \%$ of state-owned capital.

3) Foreign-invested enterprises (FEs): enterprises with 100\% of foreign direct investment; joint venture between private enterprises or state-owned enterprises with foreign partners.

These enterprises operate in all economic sectors, Agriculture, Forestry and Fishing sector (AFFS), Manufacturing sector (MS) and Service sector (SS) (Note 3). From 1986 until now Vietnamese government has made various incentives and policies on prioritizing resources for SOEs, manufacturing and service sector and thus they have affected significantly business activities. However, the privatization of SOEs, especially for small and not important ones, has been also boosted. These have significant influence on the development of enteprises in Vietnam in the recent years. There have been some empirical studies on the relationship between the performance of enterprises and different types of ownership and economic sectors such as T. Q. Nguyen (2004), T. H. Nguyen (2009), T. C. Nguyen (2012), Pham and Vuong (2009) or Hoang (2014). However, to the best of our knowledge, there has been no study about the simultaneous effects of types of ownership and economic sectors on the enterprise performance in Vietnam. Thus, in this paper we add to the literature by investigating the influence of ownership and sectoral differences on the performance of enterprises in Vietnam and make some policy implication. 
The rest of the paper is structured as follows. The next section brieftly discuss the literature and research questions. Section 3 describes data and methodology. Section 4 focuses on the results. The last section presents discussion and conclusion.

\section{Literature Review and Research Questions}

There are many studies on the impact of ownership on the businesses' efficiency. According to Hymer (1976), if foreign enterprises often benefit from the advantages of capital, technology and management skills, domestic enterprises have advantages on the understanding of traditions and local market. As a result, foreign invested enterprises and domestic enterprises will tend to have different business efficiency. For state ownership and private ownership, economic theory of Meggison and Netter (2001) predicts that private ownership is more efficient than public ownership with some assumptions such as no externalities in production or consumption, not a public good, no natural monopoly and low information costs. Sjöholm (2006) argues that although capital markets do not have the disciplinary effect on SOEs and these enterprises do not face the threat of hostile takeover but they also get some difficulties. Firstly, SOEs' objectives might not clear, maximizing profit or social welfare or political benefits. As a result, in many cases the managers of SOEs may make decisions not based on the objectives of maximizing profit and business efficiency as POEs. Secondly, for socialist systems as Vietnam, the SOEs are often bailed out by the government when they face financial difficulties and Kornai (1993) defines this as "soft budget constraint". For example, it may be soft taxation, soft subsidies, soft credit or soft administrative prices. And this leads to the passiveness of SOEs as well as the increased drain and inefficiency of government resources (Sjöholm, 2006). In contrast, for POEs, their main objective is to generate the value and maximizing profit. If not so, POEs can face the serious hostile takeover threat from competitors or/and debtors or even be forced into bankruptcy. Therefore, it is not the same as SOEs, POEs always have strong incentives for making profit and enhancing their business efficiency.

In order to assess the different impact of types of ownership on firm performance, it is necessary to answer the question (01):

\section{"Do Vietnamese enterprises of different types of ownership perform differently?"}

In addition to the impact of ownership factor, many studies have examined how economic sector or industry can specifically affect firm behavior through achieving economies of scale (Katrishen \& Scordis, 1998) or economic performance (Habib \& Victor, 1991). In fact, firm characteristics vary from one economic sector to another. For example, firm's capital structure, risk, growth, business cycle, and access to external sources of funding vary across economic sectors. Therefore, enterprise's profitability may be influenced by the sectors (Tian \& Zeitun, 2007). Besides, Olokoyo and Felicia Omowunmi (2012) indicates that although sector is significantly related to the accounting measure of firm performance (ROA) but it has a significant relationship with the market performance (Tobin's Q). In general, economic sectors have dissimilar advantages that may cause the variance in firm performance. In Vietnam, economic sectors are classified into three main groups, agriculture, forestry and fishing Sector, manufacturing sector and service Sector. The businesses in each economic sector would have different features. In other words, it seems that enterprises operating in different sectors would have different advantages leading to the variation in their performance.

In order to investigate the effect of different economic sector on enterprise performance, it is necessary to answer the question (02):

"Do Vietnamese enterprises of different economic sectors perform differently?"

The research questions (01) and (02) can only explain the separate impact of each factor, types of ownership or economic sector, on the performance of enterprises in Vietnam but not explain the simultaneous impacts of these factors. Nachum (2004) investigates 345 companies in developing countries and shows that impacts of different business areas and ownership structures on business efficiency. Lahiri and Purkayastha (2015) also concludes that business efficiency is affected by their lines of business and economics sectors when studying Indian companies from 2004 to 2008. These findings are also supported by empirical studies such as Park and Jang (2012) and Chen and Yu (2012). With the aim of investigating the simultaneous impacts of ownership and economic sector on the business efficiency of enterprises in Vietnam, the research question (03) is as follow:

\footnotetext{
"Do Vietnamese enterprises of different types of ownership or different economic sectors perform differently?"
}

In this paper we try to answer the three main questions above through the methods of One-way ANOVA and Two-way ANOVA. 


\section{Method and Data}

\subsection{Method}

In this section, we first briefly discuss the method of Analysis of Variance (ANOVA) that is used to test the hypothesis that there is no difference between population means (at least three). The conditions of reliable results of the ANOVA are:

- For each population, the dependent variable is normally distributed.

- The variance of the dependent variable must be equal.

\subsubsection{One-Way ANOVA}

One-way ANOVA analyzes the impact of only one independent variable (qualitative) on only one dependent variable (quantitative). This method tests that the population means are equal (01):

$\mathrm{H}_{0.1}$ : Population means are equal.

$\mathrm{H}_{1.1}$ : Population means are not equal.

In order to fit One-way ANOVA, the independent variable has to have at least three separate characteristics to set up three different populations. Table 1 illustrates One-way ANOVA results:

Table 1. Results of one-way ANOVA in a general format

\begin{tabular}{ccccc}
\hline Source of Variation & Sum of squares & Degree of Freedom & Mean squares & F ratio \\
\hline Between-groups & SSG & $\mathrm{k}-1$ & MSG=SSG/(k-1) & F=MSG/MSW \\
With-groups & SSW & $\mathrm{n}-\mathrm{k}$ & MSW=SSW/(n-k) & \\
Total & SST & $\mathrm{n}-1$ & & \\
\hline
\end{tabular}

Note. $\mathrm{SSG}=$ sum of squares between groups; $\mathrm{SSW}=$ sum of squares within groups; SST=total sum of squares; $\mathrm{k}=$ number of groups; $\mathrm{n}=$ observed sample.

It is possible to reject or accept the equivalence of population means of the general hypothesis (01) if we compare the value of F-ratio with the standard normal distribution table of F-value. In order to test the impact of types of ownership on the business performance by One-way ANOVA, the research question (01) above should be replaced with the following hypothesis (02):

\section{$H_{0.2}: R O A$ of enterprises with different types of ownership are equal. \\ $H_{1.2}: R O A$ of enterprises with different types of ownership are not equal.}

The only one independent variable (qualitative) in hypothesis (02) is firms' types of ownership. As mentioned above, there may be divided into three groups (three populations): state-owned enterpise (SOE), private-owned enterpise (POE) and foreign invested enterprise (FE), which match the condition of One-way ANOVA.

Likewise, in order to examine the influence of economic sector on enterprises' performance by One-way ANOVA, the research question (02) should be replaced with a hypothesis (03) as below:

$H_{0.3}$ : ROA of enterprises with different economic sectors are equal.

$H_{1.3}: R O A$ of enterprises with different economic sectors are not equal.

To satisfy the condition of One-way ANOVA (at least three populations), the independent variable (qualitative) of economic sector in hypothesis (03) are classified into three groups: Agriculture, Forestry and Fishing Sector (AFFS), Manufacturing Sector (MS), and Service Sector (SS).

\subsubsection{Two-Way ANOVA}

For the research question (03), it is necessary to use Two-way ANOVA for testing the influence of two independent variables (qualitative variables) on one dependent variable (quantitative variable). Two-way ANOVA tests general hypotheses (04):

$H_{0.4}$ : Population means are equal.

$H_{1.4}:$ Population means are not equal.

Populations of the hypothesis (04) are determined from features of two independent variables. The first independent variable has $\mathrm{K}$ feature (K groups) and the second one has B feature (B groups), which form K.B different research populations. Table 2 illustrates Two-way ANOVA results: 
Table 2. Results of two-way ANOVA in a general format

\begin{tabular}{ccccc}
\hline Source of Variation & Sum of squares & Degree of Freedom & Mean squares & F ratio \\
\hline Between-groups & SSG & K-1 & MSG=SSG/(K-1) & F1=MSG/MSE \\
Between-blocks & SSB & B-1 & MSB=SSB $/(B-1)$ & F2=MSB/MSE \\
Interaction & SSI & $($ K-1)(B-1) & MSI=SSI/(K-1)(B-1) & F3=MSI/MSE \\
Error & SSE & n-(BK-1) & MSE=SSW/(n-(KB-1)) & \\
Total & SST & N & & \\
\hline
\end{tabular}

Note. $\mathrm{SSG}=$ sum of squares between groups formed from $\mathrm{K}$ groups; $\mathrm{SSB}=$ sum of squares between groups formed from $\mathrm{K}$ groups; $\mathrm{SSI}=$ sum of squares interaction formed from K.B groups; SSE=sum of squares error; SST=sum of squares total; $n=$ observed sample.

Comparing the value of F3 with the standard normal distribution table of F-value to make a decision, reject or accept the equivalence of population means in hypothesis (04).

In order to estimate the simultaneous impact of ownership type and economic sector on enterprise performance with Two-way ANOVA, the research question (03) should be replaced with the hypothesis (05):

\section{$H_{0.5}$ : ROA of enterprises with different types of ownership or economic sectors are equal. \\ $H_{1.5}: R O A$ of enterprises with different types of ownership or economic sectors are not equal.}

The population of the hypothesis (05) is specified based on the combination of types of ownership (three groups) and economic sectors (three groups), which form the sum of nine populations. This allows testing the different influence of ownership and economic sector simultaneously on enterprises' performance.

\subsection{Data}

Source of data in this paper is from the 2015 enterprise investigation program held by The General Statistics Office of Vietnam (GSO). The survey collected the information on enterprises' resources and business results. The enterprises established since 2014 are removed from the sample because of the lack of information. The final data set used in this paper contains 4,733 surveyed enterprises in four regions, Thua Thien-Hue, Danang, Quangnam and Quangngai. Sample distribution is inherited from the structure of GSO's survey sample, apportioned based on the proportion of types of ownership and economic sectors. Therefore, the sample ensures the representativeness of estimates and testing in this research. Descriptive statistics of variables are illustrated on Appendix A and Appendix B.

Table 3. Sample distribution of enterprises by types of ownership and economic sector

\begin{tabular}{ccccc}
\hline \multirow{2}{*}{ Economic sector } & \multicolumn{2}{c}{ Type of ownership } & Total \\
\cline { 2 - 4 } & SOEs & POEs & FEs & 580 \\
\hline Agriculture, forestry and fishing & 222 & 301 & 57 & 2,137 \\
Manufacturing & 253 & 1,602 & 282 & 2,016 \\
Service & 133 & 1,565 & 318 & 4,733 \\
Total & 608 & 3,468 & 657 & \\
\hline
\end{tabular}

Source: 2015 enterprise investigation program, GSO.

The data have been tested the variance equivalence of the populations based on the Homogeneity testing standards and there are always more than 30 observations in each group (shown in Table 3). Thus, average values follow the standard distribution, meeting the requirement of ANOVA.

\section{Results}

\subsection{Impact of Types of Ownership on Enterprise Performance}

Table 4. ROA estimated results of enterprises with types of ownership

\begin{tabular}{ccccc}
\hline \multirow{2}{*}{ Types of ownership } & \multirow{2}{*}{ Number of enterprise } & Mean $(\%)$ & \multicolumn{2}{c}{ 95\% Confidence Interval for Mean } \\
\cline { 3 - 5 } & & & Lower Bound & Lower Bound \\
\hline SOEs & 608 & -0.23 & -1.58 & 3.11 \\
POEs & 3468 & 3.35 & 2.95 & 2.75 \\
FEs & 657 & 1.53 & 0.13 & 3.03 \\
Total & 4733 & 2.64 & 2.24 & \\
\hline
\end{tabular}


With the total number of 4,733 investigated enterprises, their ROA mean is estimated at $2.64 \%$ with $95 \%$ confidence interval and interval estimate from $2.24 \%$ to $3.03 \%$. In which, it seems that POEs' ROA is the highest with the point estimate of $3.35 \%$ and the interval estimate between $2.95 \%$ and $3.75 \%$. The second highest ROA mean of $1.53 \%$ belongs to FEs with their interval estimate between $0.13 \%$ and $2.94 \%$. Conversely, it is noticed that SOEs' ROA average value is very low, $-0.23 \%$ and it may be that the SOEs is far less efficient than those other types of ownership.

Table 5. ANOVA results about impact of types of ownership on enterprises' ROA

\begin{tabular}{cccccc}
\hline & Sum of Squares & Degree of freedom & Mean Square & F & Sig \\
\hline Between-Groups & $7,566.510$ & 2 & $3,783.255$ & 20.080 & .000 \\
Within-Groups & $891,194.645$ & 4,730 & 188.413 & & \\
Totals & $898,761.155$ & 4,732 & & & \\
\hline
\end{tabular}

Table 5 has Sig $=0.000<5 \%$ (The probability of making errors when disproving the null hypothesis) therefore the research has a foundation for rejecting the null hypothesis $\mathrm{H}_{0.2}$. In other words, with the $5 \%$ significant level, it is possible to conclude that types of ownership may have different impacts on the enterprises' ROA. It means that in the condition factors affecting enterprises' business efficiency are alike, but the efficiency of the enterprises is not equal if whose types of ownership are different.

Table 6. Results of ROA estimated deviation of types of ownership

\begin{tabular}{ccccc}
\hline Types of ownership & Types of ownership & Mean Difference & \multicolumn{2}{c}{$95 \%$ Confidence Interval (\%) } \\
\cline { 4 - 5 }$(\mathrm{I})$ & $(\mathrm{J})$ & 3.58 & Lower Bound & Upper Bound \\
\hline POE & SOE & 1.82 & 2.17 & 5.00 \\
POE & FE & 1.77 & 0.45 & 3.18 \\
FE & SOE & & 0.04 & 3.58 \\
\hline
\end{tabular}

Table 6 shows that it seems that there is a huge difference between the enterprises' ROA average value with different types of ownership. Accordingly, it is noticed that POEs' ROA mean are $3.58 \%$ higher than those SOEs and $1.82 \%$ higher than those FEs. Based on interval estimate with 95\% confidence level, average ROA of POEs is $2.17 \%$ - equivalent to $5 \%$ higher than SOEs and 0.45 - approximately $3.18 \%$ higher than those with FEs. ROA of FEs is higher than SOEs by point estimate being $1.77 \%$ and by interval estimate being 0.04 - about $3.58 \%$. These results show that if only considering the enterprises' performance with ROA, Vietnam should priorize for development of POEs and FEs, respectively. Because it seems that SOEs' performance is less efficient than enterprises with other types of ownership.

\subsection{Impact of Economic Sector on Enterprise Performance}

Table 7. ROA estimated results of enterprises with different economic sectors

\begin{tabular}{ccccc}
\hline \multirow{2}{*}{ Economic sector } & \multirow{2}{*}{ Number of enterprises } & \multirow{2}{*}{ Mean $(\%)$} & \multicolumn{2}{c}{ 95\% Confidence Interval for Mean } \\
\cline { 4 - 5 } & & 2.77 & Lower Bound & Lower Bound \\
\hline Agriculture, Forestry and Fishing & 580 & 2.59 & 1.73 & 3.80 \\
Manufacturing & 2137 & 2.65 & 2.03 & 3.16 \\
Service & 2016 & 2.64 & 2.24 & 3.28 \\
Total & 4733 & &
\end{tabular}

The next step is to consider the impact of different economic sector on enterprises' performance. It seems that there is not so high deviation of ROA value among enterprises in different economic sectors. According to point estimate, the enterprises' ROA average value in the sector of Agriculture and Forestry and Fishing is the highest, at $2.77 \%$. This figure is followed by Service Sector with approximately $2.65 \%$ and Manufacturing is the economic sector with the lowest ROA value of $2.59 \%$.

In addition, ANOVA results on Table 8 below shows the value of Sig $=0.964>5 \%$. Thus, it seems that there is no basis for rejecting the null hypothesis $\mathrm{H}_{0.3}$ of hypothesis (03). In other words, with the $5 \%$ significant level, it is possible to conclude: "ROA of enterprises with different economic sectors is equal". In other words, in Vietnam 
the features of economic sector do not have much influence on the business efficiency of enterprises.

Table 8. Results of ANOVA of impacts of economic sector on ROA

\begin{tabular}{cccccc}
\hline & Sum of Squares & Degree of freedom & Mean Square & F & Sig. \\
\hline Between-Groups & 13.744 & 2 & 6.872 & .036 & .964 \\
Within-Groups & 898747.411 & 4730 & 190.010 & & \\
Total & 898761.155 & 4732 & & & \\
\hline
\end{tabular}

\subsection{Simultaneous Impact of Ownership and Economic Sector on Enterprise Performance}

We continue simultaneous impacts of ownership and economic sector on enterprise performance. However, One-way ANOVA can only test the impacts of these factors on enterprises' efficiency separately. In order to test the simultaneous impacts of these factors, Two-way ANOVA is used.

With all the significant values are smaller than $5 \%$ illustrated in Table 9, it seems that the null hypothesis $H_{0.5}$ of the hypothesis (05) is rejected. It means "ROA of enterprises which with different types of ownership and economic sectors are different is unequal". In other words, the enterprises with different types of ownership and economic sectors have different business efficiency.

Table 9. ANOVA results about the impact of types of ownership and economic sector on enterprises' ROA

\begin{tabular}{cccccc}
\hline Source & Sum of Squares & Degree of freedom & Mean Square & F & Sig. \\
\hline Type of ownership & $7,062.227$ & 2 & $3,531.113$ & 18.834 & .000 \\
Economic sector & $2,602.990$ & 2 & $1,301.495$ & 6.942 & .001 \\
Type of ownership \& Economic sector & $4,842.172$ & 4 & $1,210.543$ & 6.457 & .000 \\
Errors & $885,669.885$ & 4,724 & 187.483 & & \\
Total & $931,672.510$ & 4,733 & & & \\
\hline
\end{tabular}

Detailed research on enterprises' ROA with types of ownership and economic sectors is shown in Table 10. It illustrates that for Agriculture, Forestry and Fishing Sector, FEs have the highest ROA value, at $3.98 \%$ and it is followed by SOEs with $2.67 \%$. POEs are the lowest level, approximately at $2.61 \%$. These figures may make a notice because although Vietnam is agricultural economy, SOEs' performance in this traditional economic sector is not as high as those with foreign invested.

Table 10 also shows that in Manufacture Sector and Service Sector, POEs reach the highest of ROA, 3.26\% and $3.58 \%$, respectively. These figures are higher than general average values of $2.59 \%$ and $2.65 \%$. In the meantime, the SOEs' efficiency is extremely low and remains at a loss level. It seems that POEs are often small scale and low business capital, thus it is possible for them to meet the flexibility of Service sector. ROA value of SOEs in this economic sector is worrying as it is $-4.99 \%$, which makes it obvious that they are inefficient and incompetent in comparison with those in other sectors. Futhermore, the SOEs' ROA average in manufacture sector is $-0.28 \%$. This figure is very low in comparison with the POEs' ROA of $3.58 \%$ and FEs of $1.39 \%$.

Table 10. ROA Estimated results of enterprises of ownership and economic sectors (\%)

\begin{tabular}{ccccc}
\hline \multirow{2}{*}{ Economic sector } & \multicolumn{3}{c}{ Type of Ownership } & \multirow{2}{*}{ Total } \\
\cline { 2 - 4 } & SOEs & POEs & FEs & 3.98 \\
2.77 \\
Agriculture, forestry and fishing & 2.67 & 2.61 & 1.39 & 2.59 \\
Manufacturing & -0.28 & 3.26 & 1.22 & 2.65 \\
Service & -4.99 & 3.58 & 1.53 & 2.64 \\
Total & -0.23 & 3.35 & &
\end{tabular}

\section{Discussion and Conlcusion}

The method of One-way ANOVA is used to test the individual impact of each factor, namely types of ownership and the economic sectors, on the performance of the businesses in Vietnam. The results show that types of ownership have different effects on the performance of enterprises. In the three types of enterprises surveyed, private-owned enterprises and foreign-invested enterprises had relatively high business efficiency, in which 
private-owned enterprises had a higher return on total assets. In contrast, state-owned enterprises have the poor performnance. This may be caused by unclear objectives, poor management, and soft budget constraint all contributed to the deteriorating situation as the conclusion of Sjöholm (2006). It seems that the Vietnamese government has been successful in boosting the privatization process of state-owned enterprises, expanding high efficient private-owned enterprises and foreign-invested enterprises and reduce poor state-owned enterprises and thus, they have contributed significantly to economic growth since the economic reform 1986. However, although there is a decrease in the number of inefficient SOEs, it seems that the remaining state-owned enterprises are not efficient in comparison with other types of enterprises. Our results also confirm the finding from the study of Nguyen and Freeman (2009). In addition, our research also shows that economic sector is not the factor that makes a significant difference in enterprises' efficiency in Vietnam.

However, what is probably most striking in our results is the finding that the simultaneous impact of both two factors of ownership type and economic sector on the enterprises' performance. By the method of Two-way ANOVA, the results show that the combination of these two factors creates a different impact on the business efficiency of enterprises in Vietnam. Accordingly, while foreign invested enterprise's performance in Agriculture, Forestry and Fishing sector is higher than theirs in Manufacturing and Service Sectors, this result is the opposite for the private-owned enterprises. However, it is clear that both foreign-invested enterprises and private enterprises have better efficiency than state-owned enterprises in most economic sectors.

Based on the findings, the authors make some policy implication for Vietnam though building up the rule of value as below:

1) State-owned enterprises should invest in Agriculture, Forestry and Fishing Sector because their performance in this economic sector is better than in other fields, namely Service and Manufacturing sector.

2) With their performance in Manufacturing and Service Sectors is very higher than in Agriculture, Forestry and Fishing, private-owned enterprises should focus on the first two economic sectors.

3) Foreign-invested enterprises seem to reach the highest business efficiency in Agriculture Forestry and Fishing sector at present, but in Manufacturing and Service sectors their result is not good in comparison with their own potentials.

However, so far the main limitation of this paper is the source of data. The authors can only approach survey data of 4 regions: Hue, Danang, Quangnam and Quangngai. This may lead to lack the representativeness of all enterprises in Vietnam. In the future, the authors intend to expand the survey of enterprises to all regions in Vietnam in an attempt to boost the reliability of estimated results and testing.

\section{References}

Chiung, J. C., \& Chwo, M. J. Y. (2012). Managerial ownership, diversification, and firm performance: Evidence from an emerging market. International Business Review, 21(3), 518-534. https://doi.org/10.1016/j.ibusrev.2011.06.002

Fredrik, S. (2006). State owned enterprises and equitization in Vietnam. Working Paper 228. Stockholm School of Economics.

Habib, M., \& Victor, B. (1991). Strategy, structure, and performance of US manufacturing and service MNCs: A comparative analysis. Strategic Management Journal, 12(8), 589-606. https://doi.org/10.1002/smj.4250120803

Hoàng, S. Đ. (2014). Tái cấu trúc kinh tế, đổi mới mô hình tăng trưởng trên cơ sở khai thác, phát huy tiềm năng, lợi thế. Tạp chí Nghiên cứu kinh tế, 435(08), 22-31.

Hymer S. H. (1976). The International operations of national firms: A study of direct foreign investment. Cambridge: MIT Press. URI: http://hdl.handle.net/1721.1/27375

Katrishen, F., \& Scordis, N. (1998). Economies of scale in services: A study of multinational insurers. Journal of International Business Studies, 29(2), 305-324. https://doi.org/10.1057/palgrave.jibs.8490038

Kornai, J. (1993). The Evolution of Financial Discipline under the Postsocialist System. Kyklos, 46(3), 315-336. https://doi.org/10.1111/j.1467-6435.1993.tb00512.x

Kwangmin, P., \& Soo, C. (Shawn) J. (2012). Effect of diversification on firm performance: Application of the entropy measure. International Journal of Hospitality Management, 31(1), 218-228. https://doi.org/10.1016/j.ijhm.2011.03.011 
Lahiri, S., \& Purkayastha, S. (2017). Impact of industry sector on corporate diversification and firm performance: Evidence from Indian business groups. Canadian Journal of Administrative Sciences, 34(1), 77-88. https://doi.org/10.1002/cjas.1333

Loree, D. W., \& Guisinger, S. E. (1995). Policy and non-policy determinants of US equity foreign direct investment. Journal of International Business Studies, 26(2), 281-299. https://doi.org/10.1057/palgrave.jibs.8490174

Megginson, W. L., \& Jeffrey, M. N. (2001). From State to Market: A Survey of Empirical Studies on Privatization. Journal of Economic Literature, XXXIX, 321-389. https://doi.org/10.1257/jel.39.2.321

Nachum, L. (2004). Geographic and Industrial Diversification of Developing Country Firms. Journal of Management Studies, 4l(2), 273-294. https://doi.org/10.1111/j.1467-6486.2004.00432.x

Nguyen, V. T., \& Nick, J. F. (2009). State-owned enterprises in Vietnam: are they "crowding out" the private sector? Post-Communist Economies, 21(2), 227-247. https://doi.org/10.1080/14631370902778674

Nguyễn, T. C. (2012). Tình hình phát triển kinh tế nội ngành và chuyển dịch cơ cấu kinh tế Việt Nam trong giai đoạn đổi mói và hội nhập. Sánh Chuyển dịch cơ cấu kinh tế. Mô hình tăng trưởng kinh tế thành phố Hồ Chí Minh và Việt Nam theo hướng cạnh tranh đến năm 2020, NXB Tổng Hợp TPHCM, 48-65. (Vietnamese).

Nguyễn, T. H. (2009). Đầu tư trực tiếp nước ngoài năm 2008. Tạp chí Cộng Sản, số 759, 49-56. (Vietnamese).

Nguyễn, T. Q. (2004). Chuyển dịch co cấu kinh tế Việt Nam trong nhũng năm đầu thế kỷ 21. NXB Khoa học xã hội Hà Nội. (Vietnamese).

Olokoyo, F. O. (2012). The effect of the industrial sector on firms'performance in a multi-cultural economy. International Journal of Economics, Finance and Management, 1(1), 26-32.

Phạm, M. C., \& Vương, Q. H. (2009). Kinh tế Việt Nam: Thăng trầm và đột phá. NXB Tri Thức. (Vietnamese).

Tian G. G., \& Zeitun, R. (2007). Capital Structure and Corporate Performance: Evidence from Jordan. Australasian Accounting Business \& Finance Journal, 1(4), 40-61.

United Nations. (1989). The System of National Accounts.

\section{Notes}

Note 1. The Sixth National Congress of Vietnamese Communist Party in 1986 decided on the change of Vietnamese economy from the central planning regime into market-oriented economy.

Note 2. On $29^{\text {th }}$ December 1987, Vietnamese Parliament officially passed the Law of Foreign Investment.

Note 3. In this paper, the authors classify enterprises in Vietnam operating in three main economic sectors: Agriculture, Forestry and Fishing sector (AFFS), Manufacturing sector (MS) and Service sector (SS). This classification approach is suitable for International Standard Industrial Classification of all Economic Activities (ISIC) and the Decision 10/2007/QD-TT announced in 2007 by Vietnamese Government.

\section{Appendix A}

\section{Descriptive Statistics of Independent Variables}

\begin{tabular}{ccccccccc}
\hline \multirow{2}{*}{ Variable } & \multirow{2}{*}{$\mathrm{N}$} & \multirow{2}{*}{ Mean } & \multirow{2}{*}{ SD } & \multirow{2}{*}{ SE } & \multicolumn{2}{c}{ 95\% Confidence Interval for Mean } & \multirow{2}{*}{ Min } & \multirow{2}{*}{ Max } \\
& & & & & Lower Bound & Upper Bound & & \\
\hline SOEs & 608 & -0.2329 & 16.91850 & 0.68614 & -1.5804 & 1.1145 & -194.50 & 80.58 \\
POEs & 3468 & 3.3491 & 11.97584 & 0.20336 & 2.9504 & 3.7479 & -231.65 & 241.86 \\
FEs & 657 & 1.5336 & 18.32173 & 0.71480 & 0.1300 & 2.9372 & -113.55 & 241.86 \\
AFFS & 580 & 2.7655 & 12.71864 & 0.52811 & 1.7283 & 3.8028 & -46.38 & 241.86 \\
MS & 2137 & 2.5937 & 13.32710 & 0.28829 & 2.0283 & 3.1591 & -194.50 & 200.30 \\
SS & 2016 & 2.6458 & 14.53511 & 0.32372 & 2.0110 & 3.2807 & -231.65 & 241.86 \\
Total & 4733 & 2.6370 & 13.78160 & 0.20032 & 2.2442 & 3.0297 & -231.65 & 241.86 \\
\hline
\end{tabular}

Note. $\mathrm{SD}=$ standard deviation; $\mathrm{SE}=$ standard error; $\mathrm{N}=$ number of enterprises. 


\section{Appendix B}

Descriptive Statistics of Dependent Variable (ROA)

\begin{tabular}{|c|c|c|c|c|c|c|c|c|c|}
\hline \multirow{2}{*}{$\begin{array}{c}\text { Economic } \\
\text { sector } \\
\end{array}$} & \multicolumn{3}{|c|}{ SOEs } & \multicolumn{3}{|c|}{ POEs } & \multicolumn{3}{|c|}{ FEs } \\
\hline & Mean & SD & $\mathrm{N}$ & Mean & SD & $\mathrm{N}$ & Mean & Std & $\mathrm{N}$ \\
\hline AFFS & 2.669 & 9.08658 & 222 & 2.6065 & 5.81506 & 301 & 3.9812 & 34.11528 & 57 \\
\hline MS & -0.2785 & 20.75884 & 253 & 3.2584 & 12.1986 & 1602 & 1.3947 & 10.21919 & 282 \\
\hline SS & -4.9901 & 17.84271 & 133 & 3.5849 & 12.60736 & 1565 & 1.2181 & 19.88216 & 318 \\
\hline Total & -0.2329 & 16.9185 & 608 & 3.3491 & 11.97584 & 3468 & 1.5336 & 18.32173 & 657 \\
\hline
\end{tabular}

Note. $\mathrm{SD}=$ standard deviation; $\mathrm{N}=$ number of enterprises.

\section{Copyrights}

Copyright for this article is retained by the author(s), with first publication rights granted to the journal.

This is an open-access article distributed under the terms and conditions of the Creative Commons Attribution license (http://creativecommons.org/licenses/by/4.0/). 